\title{
Effects on the nervous system in different groups of workers exposed to aluminium
}

\author{
A Iregren, B Sjögren, K Gustafsson, M Hagman, L Nylén, W Frech, M Andersson, \\ K G Ljunggren, A Wennberg
}

\begin{abstract}
Objective-To investigate possible neurotoxic effects in groups of aluminium pot room and foundry workers, aluminium welders, and a small group of workers exposed to aluminium in the production of flake powder.

Methods-Exposure to aluminium was evaluated with aluminium concentrations in blood and urine as well as a questionnaire. The groups exposed to aluminium were compared with a group of mild steel welders. Neurotoxic effects were studied with mood and symptom questionnaires and several psychological and neurophysiological tests.

Results-The pot room and foundry workers showed very low aluminium uptake as their aluminium concentrations in blood and urine were close to normal, and no effects on the nervous system were detected. The group of workers exposed to flake powder had high concentrations of aluminium in blood and urine, even higher than those of the aluminium welders. However, aluminium could not be shown to affect the functioning of the nervous system in flake powder producers. Although significant effects could not be shown in the present analysis of the data on welders, the performance of the welders exposed to high concentrations of aluminium was affected according to the analyses in the original paper from this group.
\end{abstract}

Conclusions-For the pot room and foundry workers no effects related to the exposure to aluminium could be found. For the group of flake powder producers exposed for a short term no effects on the nervous systems were evident despite high levels of exposure. Due to the high concentrations of aluminium in the biological samples of this group, measures to reduce the exposure to aluminium are recommended, as effects on the central nervous system might develop after protracted exposures. However, this assumption needs to be verified in further studies.

(Occup Environ Med 2001;58:453-460)

Keywords: aluminium; workers; nervous system

Formerly at

Företagshälsan,

Jönköping, Sweden

K G Ljunggren

Correspondence to:

Dr A Iregren

anders.iregren@niwl.se

Accepted 14 March 2001 such cases were diagnosed in Sweden. As the dust concentrations in the aluminium industry were reduced, no further cases were reported.

In the 1940s and 1950s industrial exposure to aluminium caused pulmonary fibrosis in workers producing aluminium powder, ${ }^{1}$ and five
For patients undergoing dialysis due to renal failure, a severe encephalopathy caused by accumulation of aluminium in the brain was reported in the $1970 \mathrm{~s}^{2}$ The interest in the effects of aluminium on biological systems was therefore renewed. As dialysis procedures were later modified, these severe neurotoxic effects from aluminium could be avoided. ${ }^{3}$

More recently, exposure to aluminium was suggested as a contributing factor to the development of Alzheimer's disease (AD) ${ }^{4}$ However, despite numerous scientific studies, there is still no conclusive evidence that aluminium actually contributes to the development of AD. ${ }^{5}$ Although there is a lack of evidence about the cause of this disease, high body loads of aluminium are without question toxic to the central nervous system (CNS), and there are more than 100 reported toxic activities of aluminium at the cellular level. ${ }^{6}$

In Swedish aluminium industries, exposure was surveyed in a series of studies. ${ }^{7-9}$ The highest concentrations of aluminium in blood and urine were found in workers producing aluminium flake powder and in aluminium welders, whereas concentrations were much lower in workers at primary smelters and foundries.

In 1990 neurotoxic effects of aluminium were indicated in studies of three different groups of workers. ${ }^{10-12}$ Hosovski et $a l^{10}$ reported performance deficits in foundry workers. The second study, by Rifat et al, ${ }^{11}$ showed doserelated effects on the cognitive abilities of miners exposed to aluminium dust. The third study, by Sjögren $e t a^{12}$ reported on symptom frequencies in several groups of welders. Those exposed to aluminium for many years reported more symptoms than other welders.

During the past decade, four other studies on aluminium welders were published. ${ }^{13-16}$ Two studies of aluminium welders in Finland ${ }^{13} 15$ reported effects on cognitive functions. In our study of welders ${ }^{14}$ the aluminium welders performed worse than the mild steel welders on four different tests of motor functions. The most recent study on CNS functions of 20 aluminium welders ${ }^{16}$ reported effects on hand tremor and reaction time.

The few studies of workers in aluminium smelters ${ }^{17-19}$ reported somewhat varying results, but the general impression from these studies is that the exposure levels normally are very low in this group.

We have found only one brief report on possible CNS effects from exposure to aluminium in the powder industry. ${ }^{20} \mathrm{~A}$ group of 32 workers exposed to aluminium powder with high aluminium concentrations in plasma and urine 
were studied, but no effects on the CNS could be shown.

Summarising previous research, it seems that exposure to aluminium affects workers differently in different industries. Five out of five studies indicate effects on the CNS from welding in aluminium, although neither primary nor secondary smelting seem to produce any clearly evident toxic effects on the CNS. The single study on aluminium powder production did not report any effects on the nervous system despite high concentrations of aluminium in blood and urine.

The present study was undertaken to investigate possible neurotoxic effects in a group of aluminium pot room and foundry workers, in a group of aluminium welders, and in a small group of workers exposed to aluminium in the production of flake powder. Data for these groups were compared with those of welders without exposure to aluminium.

\section{Methods}

This paper summarises data from three studies of workers exposed to aluminium in different industries.

\section{POT ROOM AND FOUNDRY WORKERS}

Two groups of aluminium smelter workers from two different work sites were included in the study. At one site all the 59 foundry workers were invited to participate, and one refused. At the other site there were some 300 workers with at least 5 years of employment. For the selection of the study group these workers were stratified into age groups with a range of 5 years. In each of these age stratified groups the workers with the longest and the workers with the shortest duration of employment were invited to participate. This procedure was adopted to reduce the correlation between age and seniority at work. A total of 69 workers were invited from this site, and eight of them refused to participate. From the two work sites, a total of 86 foundry workers and 33 workers from the pot room participated. These 119 workers were aged 24-63 years (table 1), all male, and occupationally exposed to aluminium for at least 5 years.

\section{FLAKE POWDER PRODUCTION WORKERS}

One study group was exposed to aluminium during the production of flake powder. This powder is used, for example, in the production of explosives, fireworks, colour pigment, and roof coverage. The work force at this site comprised 18 male workers with ages varying from 22 to 48 years. These workers were exposed also to white spirit vapours, as this solvent is

Table 1 Medians (ranges) age, seniority, and alcohol consumption for the four different study groups

\begin{tabular}{|c|c|c|c|c|}
\hline & \multirow{2}{*}{$\begin{array}{l}\text { Reference group } \\
\begin{array}{l}\text { Mild steel welders } \\
(n=39)\end{array}\end{array}$} & \multicolumn{3}{|c|}{ Groups exposed to aluminium } \\
\hline & & $\begin{array}{l}\text { Smelters } \\
(n=119)\end{array}$ & $\begin{array}{l}\text { Flake powder } \\
(n=16)\end{array}$ & $\begin{array}{l}\text { Welders } \\
(n=38)\end{array}$ \\
\hline Age & $39.0(23-59)$ & $46.1(24-63)$ & $34.7(22-48)$ & $38.0(26-56)$ \\
\hline Seniority & $12(5-30)$ & $15(5-40)$ & $8(2-22)$ & $15(5-35)$ \\
\hline Alcohol index & $2(0-5)$ & $2(0-6)$ & $1(0-5)$ & $2(0-5)$ \\
\hline
\end{tabular}

used in the flake powder mills to prevent explosion. The white spirit concentrations have been measured to vary between 24 and 99 $\mathrm{mg} / \mathrm{m}^{3}$ (mean $76 \mathrm{mg} / \mathrm{m}^{3}$ ). The present Swedish occupational limit for white spirit is 300 $\mathrm{mg} / \mathrm{m}^{3}$, which means that the average exposure to white spirit for these workers was around $25 \%$ of the Swedish occupational limit. All the 18 workers engaged in flake powder production were tested, but two of them were later excluded from the statistical evaluation. These two workers were excluded on medical grounds, as before our study they were diagnosed with diseases not related to exposure to aluminium that might negatively affect the functioning of the CNS.

\section{ALUMINIUM WELDERS}

A group of 38 welders, aged $26-56$ years, with a minimum of 5 years of occupational exposure to aluminium was also included. This group has been described in detail elsewhere. ${ }^{14}$

\section{MILD STEEL WELDERS}

A group of welders with no known exposure to neurotoxic substances were included as a reference group. The age span in this group of 39 workers was $23-59$ years. These steel welders were also described in our previous report. ${ }^{14}$

\section{EXPOSURE MEASURES}

Working hours and exposure were studied with a questionnaire, and exposure was also measured by blood and urine concentrations of aluminium.

The concentrations of aluminium in urine of the welders after the shift were calculated according to an equation determined in a previous study. ${ }^{9}$ All biological samples from the smelter workers were collected at least 16 hours after their latest exposure. The samples from most of the flake powder production workers were collected after 5 exposure free days.

As the neurotoxic metals manganese and lead might confound the study results, concentrations of these metals in blood were also measured. The materials used for sampling and storing of blood and urine were all continuously tested for the release of aluminium, lead, and manganese, and certified reference materials were used for quality assurance. Measurements were performed by graphite furnace atomic absorption spectrometry with Zeeman effect background correction. For details of the sampling, analysis, and quality assurance procedures we refer to our previous publication. ${ }^{14}$

\section{QUESTIONNAIRES}

Apart from the questionnaire on exposure, several other computerised as well as paper and pencil rating scales were used to measure symptoms and mood. These scales have also been described before. ${ }^{14} \mathrm{~A}$ total of 30 symptom indices were calculated from the various questionnaires. An index of alcohol habits was calculated from 10 questions on drinking habits and amount of alcoholic beverages consumed 
the week before testing. The maximum possible value of the index is 10 .

PSYCHOLOGICAL EXAMINATION

Effects on performance were studied with seven tests from the Swedish performance evaluation system. ${ }^{21}$ The tests used were simple reaction time, finger tapping speed, finger tapping endurance, digit span, vocabulary, tracking, and symbol digit coding. ${ }^{14}{ }^{21}$ Two tests of motor function, the Luria-Nebraska motor scale $^{22}$ and a board test (cylinders), described briefly in our publication on the welders, ${ }^{14}$ were also included in the test battery. These tests were used in all four groups. In the smelter group and the flake powder producers we also used a test of hand tremor from the CATSYS system developed by Danish Product Development.

\section{NEUROPHYSIOLOGICAL EXAMINATIONS}

Diadochokinesis refers to the ability to perform rapidly alternating movements with a limb, such as supination-pronation of the forearm. This test measures coordination, which is controlled by the extrapyramidal nervous system. The test procedure is further described in our previous publication. ${ }^{14}$

An electroencephalogram (EEG) was performed according to clinical practice, and electrodes were placed according to the international 10/20 system. Recordings were performed with the subject in a semireclined position with eyes closed. The EEG signal was inspected by oscilloscope, and recordings of 3 minutes on magnetic tape were performed. The printouts from these recordings were evaluated manually in four categories according to clinical practice, and the frequency of the alpha activity was calculated by counting manually the number of alpha waves during 1 second in three randomly chosen segments of the EEG curve. A further evaluation was made in the form of a spectral analysis, with the Labview program for the Macintosh computer. This analysis comprised the frequency range $1-25 \mathrm{~Hz}$ (total effect). Results are presented as relative effect (\% of total effect) for each of the following four frequency ranges: delta (1.5-3.5 $\mathrm{Hz})$, theta $(3.5-7.5 \mathrm{~Hz})$, alpha $(7.5-12.5 \mathrm{~Hz})$, and beta $(12.5-20 \mathrm{~Hz})$.

STATISTICAL METHODS

All statistical analyses were performed with the SPSS version 6.1 for Macintosh computers.

Table 2 Medians (ranges) for the exposure data of the four different study groups

\begin{tabular}{|c|c|c|c|c|}
\hline & \multirow{2}{*}{$\begin{array}{l}\text { Reference group } \\
\begin{array}{l}\text { Mild steel welders } \\
(n=39)\end{array}\end{array}$} & \multicolumn{3}{|c|}{ Groups exposed to aluminium } \\
\hline & & $\begin{array}{l}\text { Smelters } \\
(n=119)\end{array}$ & $\begin{array}{l}\text { Flake powder } \\
(n=16)\end{array}$ & $\begin{array}{l}\text { Welders } \\
(n=38)\end{array}$ \\
\hline \multicolumn{5}{|c|}{ Aluminium concentration: } \\
\hline Blood $(\mu \mathrm{g} / \mathrm{l})$ & $1.0(\mathrm{dl}-11)$ & $1.0(\mathrm{dl}-18)$ & $9.0(\mathrm{dl}-21)$ & $3.0(\mathrm{dl}-27)$ \\
\hline Urine $(\mu \mathrm{g} / \mathrm{l})$ & $3.0(\mathrm{dl}-26)$ & $4.0(\mathrm{dl}-34)$ & $83.0(12-282)$ & $22.0(4-255)$ \\
\hline $\begin{array}{l}\text { Urine }(\mu \mathrm{g} / \mathrm{g} \\
\text { creatinine) }\end{array}$ & $4.7(\mathrm{dl}-25)$ & $4.2(\mathrm{dl}-23)$ & $59.0(12-139)$ & $24.0(4.5-162)$ \\
\hline \multicolumn{5}{|c|}{ Manganese concentration: } \\
\hline Blood $(\mu \mathrm{g} / \mathrm{l})$ & $7.0(2-16)$ & $6.0(1-17)$ & $8.5(5-12)$ & $8.0(2-17)$ \\
\hline \multicolumn{5}{|l|}{ Lead concentration: } \\
\hline Blood $(\mu \mathrm{g} / \mathrm{l})$ & $42(8-76)$ & $22(6-89)$ & $14(\mathrm{dl}-31)$ & $36(17-92)$ \\
\hline
\end{tabular}

$\mathrm{dl}=$ Detection limit for the method $(<1 \mu \mathrm{g} / \mathrm{l})$.
Due to the variability of group sizes, mean differences between the four groups were tested with multiple regression. The distribution of the outcome variables in the different groups was checked by inspection of graphs of the data, and by calculation of range, skew, and kurtosis for each variable. A few of the dependent variables, mostly symptom indices, showed distributions motivating transformation of the variable before the regression analysis. Such transformations, however, did not change the outcome of the analyses or the interpretation of group differences. Age differences between the groups were controlled by forcing age into the regression before entering the group variables simultaneously. Significance for the group differences were adjusted according to the Bonferroni method for all variables where significant overall results were obtained, and a $5 \%$ level of significance was chosen.

Dose-effect relations were evaluated in two ways. Correlation coefficients were calculated for the relations between all the effect variables and the various exposure indices. Secondly, the aluminium smelter group was divided into subgroups with increasing concentrations of aluminium in urine. The concentrations in the subgroups were up to $3.0 \mu \mathrm{g} / 1,3.0-5.2 \mu \mathrm{g} / 1$, and above $5.2 \mu \mathrm{g} / \mathrm{l}$, and analysis of variance (ANOVA) was used to study possible dose related differences between these subgroups. A $5 \%$ significance level was also used for these analyses. Furthermore, a monotonous effect change with increasing exposure was required for considering any difference between subgroups to be dose related.

\section{Results}

BACKGROUND DATA

Data on age, seniority, and alcohol habits for the different groups of workers are presented in table 1 . The median age of the flake powder producers was 35 years, and their seniority was 8 years. Both the welders and the smelters were significantly older and had been employed for longer periods. There were no differences between the groups for alcohol consumption or alcohol habits in general. Data on education were not available for the welder groups.

\section{EXPOSURE DATA}

Concentrations of aluminium, manganese, and lead in blood, and also aluminium in urine are presented in table 2 . For the smelters, the concentration of aluminium in urine was $4.0 \mu \mathrm{g} / 1$ (median), with a range from below the detection limit up to $34 \mu \mathrm{g} / 1$. Corresponding values for the welders were 22.0 and 4-255. The flake powder producers had substantially higher concentrations of aluminium in blood as well as urine when compared with the other groups. The urinary concentration of aluminium was $83.0 \mu \mathrm{g} / 1$ (median), range 12-282. There was no association between seniority and concentration of aluminium in urine. There was, however, a negative correlation between concentration of aluminium in blood and seniority among the flake powder producers. No association between concentrations of aluminium in urine and performance of 
specific work tasks could be identified for any group. The flake powder producers had a lower concentration of lead in their blood than the other groups. The manganese concentrations did not differ between groups.

SYMPTOMS

A total of 30 symptom indices from the different questionnaires were evaluated. The regression analysis showed significant effects from age for four indices (pains, symptoms from ears and eyes, white fingers, and the activity index from the mood scale). The activity rating decreased with age, whereas the other indices increased. There were significant group differences for five indices (CNS problems, pains, white fingers, sleep disturbances, and stress from the mood scale). Two of these differences (white fingers and stress from the mood scale) did, however, disappear when age or blood lead concentration was controlled for in the analysis. The regression analyses showed a higher prevalence of CNS symptoms during testing for the smelters and the group exposed to flake powder compared with the steel welders. The steel welders reported pains more often than the other groups, and also more often complained about white fingers than the smelters. The smelter group more often reported sleep disturbances compared with the steel welders.

PSYCHOLOGICAL AND TREMOR TESTS

Means for the outcome variables of the psychological tests and the tremor test are presented in table 3, together with $p$ values for the significance tests of group differences. The regression analysis showed a significant effect of age on all performance variables but two.
Finger tapping speed for the non-dominant hand and the mean performance on the test of simple reaction time were not related to age. For the variables that were affected by age, performance declined with increasing age for all variables except the number of correct responses to the verbal test.

Significant group differences were found for the peg board test (cylinders), the tracking task, and for simple reaction time. The mild steel welders performed better than the aluminium smelters on the cylinders peg board test, the tracking test, and the test of simple reaction time. On the tracking test the steel welders also performed better than the workers exposed to flake powder. No significant differences were found with the tremor test. There were no correlations between aluminium concentrations in urine or blood and the outcome measures.

NEUROPHYSIOLOGICAL MEASURES

Data from the analyses of the EEGs are presented in table 4 , where the $\mathrm{p}$ values for the significance tests of group differences are also given. There were no significant differences between the groups, neither for the visual inspections nor for the frequency analysis of the energy spectrum. Table 5 shows mean values and $p$ values for mean differences for the measures of the diadochokinesometric test. Table 5 shows that there is a significant result for exposure in the overall regression analysis. However, this effect is too weak to reach significance in the Bonferroni test, but there is an indication of an increased amplitude for aluminium welders compared with the reference group.

Table 3 Means (SD) for performance variables from the psychological tests and for the tremor test ( $p$ values for group differences are also presented)

\begin{tabular}{|c|c|c|c|c|c|}
\hline \multirow[b]{2}{*}{ Variable } & \multirow{2}{*}{$\begin{array}{l}\text { Reference group } \\
\begin{array}{l}\text { Mild steel welders } \\
(n=39)\end{array}\end{array}$} & \multicolumn{3}{|c|}{ Groups exposed to aluminium } & \multirow[b]{2}{*}{$\begin{array}{l}p \text { Value for mean } \\
\text { differences }\end{array}$} \\
\hline & & $\begin{array}{l}\text { Smelters } \\
(n=119)\end{array}$ & $\begin{array}{l}\text { Flake powder } \\
(n=16)\end{array}$ & $\begin{array}{l}\text { Welders } \\
(n=38)\end{array}$ & \\
\hline \multicolumn{6}{|l|}{ Finger tapping speed: } \\
\hline Dominant hand & $66.1(8.3)$ & $64.7(9.0)$ & $65.2(6.7)$ & $63.8(8.8)$ & NS \\
\hline Non-dominant hand & $62.3(9.3)$ & $57.5(9.3)$ & $58.2(7.3)$ & $57.3(10.4)$ & NS \\
\hline Finger tapping endurance & $295.1(47.1)$ & $359.0(50.1)$ & $365.8(45.9)$ & $299.2(62.2)$ & NS \\
\hline \multicolumn{6}{|l|}{ Luria-Nebraska: } \\
\hline Task 1 & $7.8(1.5)$ & $7.2(1.7)$ & $8.8(1.7)$ & $7.9(1.8)$ & NS \\
\hline Task 2 & $7.9(1.6)$ & $7.1(1.8)$ & $9.1(1.7)$ & $7.6(1.7)$ & NS \\
\hline Task 3 & $21.5(4.9)$ & $19.2(7.0)$ & $18.7(3.5)$ & $19.1(5.2)$ & NS \\
\hline Task 4 & $22.7(5.1)$ & $20.4(6.9)$ & $21.8(4.3)$ & $19.7(5.2)$ & NS \\
\hline Task 5 & $15.3(4.5)$ & $13.5(4.8)$ & $13.5(3.9)$ & $13.9(4.3)$ & NS \\
\hline Task 21 & $14.7(4.8)$ & $12.3(4.8)$ & $16.2(5.6)$ & $13.1(5.1)$ & NS \\
\hline Task 23 & $12.5(3.0)$ & $11.6(4.2)$ & $13.1(5.0)$ & $11.9(3.6)$ & NS \\
\hline \multicolumn{6}{|l|}{ Cylinder peg board: } \\
\hline Dominant hand & $45.3(3.7)$ & $40.5^{\star}(4.8)$ & $44.1(2.9)$ & $43.5(3.8)$ & $\mathrm{p}<0.001$ \\
\hline Non-dominant hand & $41.8(3.7)$ & $37.9 \star(4.4)$ & $40.8(4.0)$ & $40.8(3.5)$ & $\mathrm{p}<0.005$ \\
\hline Tracking (mean deviation) & $11.7(4.0)$ & $21.7 \star(7.7)$ & $14.3^{\star}(3.7)$ & $12.6(4.0)$ & $\mathrm{p}<0.001$ \\
\hline \multicolumn{6}{|l|}{ Simple reaction time: } \\
\hline Mean reaction time (ms) & $223.3(20.4)$ & $243.7 \star(34.5)$ & $233.2(20.1)$ & $233.9(42.3)$ & $\mathrm{p}<0.05$ \\
\hline Variability of reaction time $(\mathrm{ms})$ & $43.3(13.1)$ & $45.7(22.7)$ & $35.4(8.7)$ & $45.8(20.6)$ & NS \\
\hline \multicolumn{6}{|l|}{ Symbol digit coding: } \\
\hline Mean latency (s) & $2.9(0.6)$ & $2.9(0.8)$ & $2.8(0.5)$ & $3.1(0.6)$ & NS \\
\hline \multicolumn{6}{|l|}{ Digit span memory: } \\
\hline Mean span & $6.6(1.4)$ & $6.0(1.2)$ & $6.2(0.7)$ & $6.3(1.0)$ & NS \\
\hline Max span & $7.4(2.0)$ & $7.2(1.4)$ & $7.3(1.0)$ & $7.6(0.9)$ & NS \\
\hline \multicolumn{6}{|l|}{ Synonyms: } \\
\hline Correct responses (n) & $22.8(9.7)$ & $23.0(8.4)$ & $18.4(8.0)$ & $21.3(9.3)$ & NS \\
\hline \multicolumn{6}{|l|}{ Tremor: } \\
\hline Total index & - & $86.2(21.9)$ & $95.1(19.0)$ & - & NS \\
\hline Intensity & - & $0.15(0.07)$ & $0.13(0.05)$ & - & NS \\
\hline Central frequency & - & $7.3(1.0)$ & $7.5(1.2)$ & - & NS \\
\hline
\end{tabular}

Bold type $^{\star}=$ group means that according to the Bonferroni test differ from the mild steel welder group. 
Table 4 Means (SD) for the outcome variables from the EEG measurements ( $p$ values for group differences are also presented)

\begin{tabular}{|c|c|c|c|c|c|}
\hline \multirow[b]{2}{*}{ Variable } & \multirow{2}{*}{$\begin{array}{l}\text { Reference group } \\
\text { Mild steel } \\
\text { welders }(n=39)\end{array}$} & \multicolumn{3}{|c|}{ Groups exposed to aluminium } & \multirow{2}{*}{$\begin{array}{l}p \text { Value } \\
\text { for mean } \\
\text { differences }\end{array}$} \\
\hline & & $\begin{array}{l}\text { Smelters } \\
(n=119)\end{array}$ & $\begin{array}{l}\text { Flake powder } \\
(n=16)\end{array}$ & $\begin{array}{l}\text { Welders } \\
(n=38)\end{array}$ & \\
\hline \multicolumn{6}{|l|}{ Visual ratings: } \\
\hline Frequency of alpha activity & $9.9(0.6)$ & $9.7(0.8)$ & $9.9(0.6)$ & $9.6(0.8)$ & NS \\
\hline Pathological EEGs (\%) & 13 & 18 & 13 & 29 & NS \\
\hline \multicolumn{6}{|l|}{ Frequency analysis: } \\
\hline \multicolumn{6}{|l|}{ F3-C3 / F4-C4 } \\
\hline$\%$ Delta & $25.1(7.7)$ & $23.2(6.1)$ & $22.8(6.8)$ & $23.8(7.7)$ & NS \\
\hline$\%$ Theta & $16.1(3.9)$ & $17.4(5.1)$ & $16.3(4.0)$ & $17.1(4.6)$ & NS \\
\hline$\%$ Alpha & $23.2(11.7)$ & $23.8(12.0)$ & $25.2(15.9)$ & $26.9(16.2)$ & NS \\
\hline$\%$ Beta & $13.4(8.0)$ & $14.2(6.2)$ & $10.9(5.0)$ & $11.7(5.6)$ & NS \\
\hline \multicolumn{6}{|l|}{ P3-O1 / P4-O2: } \\
\hline$\%$ Delta & $15.3(6.9)$ & $18.2(8.6)$ & $17.9(9.9)$ & $15.7(8.6)$ & NS \\
\hline$\%$ Theta & $13.9(4.6)$ & $17.0(7.9)$ & $15.2(6.6)$ & $14.5(6.5)$ & NS \\
\hline$\%$ Alpha & $42.8(17.5)$ & $40.1(19.8)$ & $43.8(21.5)$ & $45.3(22.5)$ & NS \\
\hline$\%$ Beta & $14.2(5.7)$ & $12.6(6.6)$ & $9.5(3.0)$ & $12.5(6.9)$ & NS \\
\hline
\end{tabular}

Table 5 Means (SD) for the outcome variables from the test of diadochokinesometric functions ( $p$ values for group differences are also presented)

\begin{tabular}{|c|c|c|c|c|c|}
\hline \multirow[b]{2}{*}{ Variable } & \multirow{2}{*}{$\begin{array}{l}\text { Reference group } \\
\begin{array}{l}\text { Mild steel } \\
\text { welders }(n=39)\end{array}\end{array}$} & \multicolumn{3}{|c|}{ Aluminium exposed groups } & \multirow{2}{*}{$\begin{array}{l}p \text { Value } \\
\text { for mean } \\
\text { differences }\end{array}$} \\
\hline & & $\begin{array}{l}\text { Smelters } \\
(n=119)\end{array}$ & $\begin{array}{l}\text { Flake powder } \\
(n=16)\end{array}$ & $\begin{array}{l}\text { Welders } \\
(n=38)\end{array}$ & \\
\hline \multicolumn{6}{|l|}{ Frequency: } \\
\hline Dominant hand & $2.86(0.52)$ & $2.81(0.72)$ & $3.10(0.72)$ & $2.69(0.62)$ & NS \\
\hline Non-dominant hand & $2.67(0.44)$ & $2.50(0.55)$ & $2.89(0.60)$ & $2.49(0.53)$ & NS \\
\hline \multicolumn{6}{|l|}{ Amplitude: } \\
\hline Dominant hand & $97.2(15.8)$ & $97.1(17.5)$ & $98.8(14.7)$ & $104.6(15.6)$ & $\mathrm{p}<0.05$ \\
\hline Non-dominant hand & $101.0(15.17)$ & $103.019 .7)$ & $98.9(11.1)$ & $106.5(16.6)$ & NS \\
\hline
\end{tabular}

\section{Discussion}

AIM

The present paper summarises data from three different studies of workers exposed to aluminium, with the aim of comparing the results and relating them to exposure. Thus, pot room and foundry workers, a small group of aluminium flake powder producers, and a group of aluminium welders were studied, and data for these aluminium exposed workers were compared with those of a control group of mild steel welders.

REFERENCE GROUP

Ideally each of these exposed groups should be compared with a group with similar work and social background, but without exposure to aluminium. Such a group could be found only for the aluminium welders. Consequently we did not try to recruit reference groups for smelters or flake powder producers, but compared these groups also with the mild steel welders that constituted the reference group in our welder study.

POWER LOSS

The median age of the flake powder producers was 35 years, and their seniority was 8 years. Both the welders and the smelters were significantly older and had more years of employment. For this reason, age was taken into account in all analyses of the data. Furthermore, as the number of workers varied widely between groups, statistical analyses were performed with regression analysis, and the Bonferroni corrections gave much higher $p$ values. Obviously these facts reduced the power of the analysis, as can be seen when comparing the present results with the original analysis of our welder groups. ${ }^{14}$ In the original analysis, corrections for age did not have to be done as the groups were age matched, ANOVA methods were used as group sizes were similar, and no adjustment of the $\mathrm{p}$ values was needed. With this methodology, significant effects from exposure to aluminium on the motor functions were found for several of the tests, findings that cannot be shown with the statistical methods appropriate for the present group comparisons.

POSSIBLE CONFOUNDING FACTORS

The blood concentrations of lead and manganese were measured to allow control for possible confounding of the results from these two neurotoxic metals. The flake powder producers had a lower concentration of lead in their blood than the other groups. Normal concentrations of lead in blood for workers not occupationally exposed to lead are below $100 \mu \mathrm{g} / 1$. All the workers in this study had concentrations in blood below that concentration, and group means were very low. Furthermore, there were no correlations between blood lead concentrations and the effect measures. Thus, lead can safely be excluded as a confounding factor for our results.

Normal concentrations of manganese in blood are not as well established as those for lead. However, the median values and ranges for our study groups are very similar to data reported from a recent Canadian population based study of manganese. ${ }^{23}$ Manganese concentrations in blood did not differ between groups in the present study. The median concentrations as well as ranges were similar for all the groups, and there were no correlations between manganese concentrations in blood and the effect measures. Manganese can thus also be ruled out as a confounding factor for our results.

Exposure to white spirit could have been a confounding factor for the results of the flake powder producers. However, the exposure concentrations were quite low at about $25 \%$ of the Swedish occupational exposure limit, white spirit is a solvent with relatively low neurotoxic potential, and no effects were found in the workers at the flake powder industry.

Irregular working hours due to shift work is another factor that potentially might confound comparisons between our study groups. To prevent the confounding with effects from sleep disturbances workers on rotating shifts were tested after at least 5 days with normal night sleeping hours. As the only group where substantial effects from exposure to aluminium were documented, ${ }^{14}$ the welders, were not working shifts, this factor is probably not affecting our results to any major extent. Still, there is an indication in our data that there could be a slight effect from shift work in the pot room and foundry workers, as they more often than the steel welders reported sleep disturbances in a symptom questionnaire.

Indices of alcohol consumption and habits were calculated from items included in the questionnaires, and no differences were found between the worker groups studied. Thus, confounding from alcohol consumption is probably not an issue for this study. 
Possible differences in level of education between our study groups could not be fully controlled as data on education were lacking for the welder groups.

POT ROOM AND FOUNDRY WORKERS

The performance differences found between mild steel welders and aluminium smelters do not seem to be related to exposure to aluminium, although they are significant in the final analysis. When the performance variables for the peg board test, the tracking task, and the simple reaction time test were analysed within the smelter group, they were not correlated with urinary concentrations of aluminium. This is true both for correlation analysis and for an analysis of variance over groups with increasing concentrations of aluminium in urine. Thus, the differences between steel welders and aluminium smelters are probably due to factors other than aluminium, and explained by the fact that the groups are not comparable.

In a Norwegian study of retired pot room workers a test for tremor discriminated significantly between exposed and blue collar referents. ${ }^{18}$ The mean urinary aluminium concentration of the 14 potroom workers was $13 \mu \mathrm{g} / \mathrm{l}$, but the interval from last exposure to examination was on average 22 days. The urine concentration after the shift was probably higher as the mean urinary aluminium concentration of the non-retired colleagues working in the same potroom was $54 \mu \mathrm{g} / \mathrm{l}$. In this study all our foundry and potroom workers had urinary concentrations of aluminium below $40 \mu \mathrm{g} / \mathrm{l}$ and the performance variables did not correlate with urinary concentrations of aluminium.

Hosovski et $a l^{10}$ studied 87 workers exposed at an aluminium foundry. Reported effects included slower psychomotor reactions and reduced coordination, as well as memory problems and other mental disturbances. This study is, however, somewhat difficult to interpret due to the high concentrations of aluminium in blood. Aluminium concentrations in blood were much higher than those in urine, both for exposed and reference workers. This is not consistent with the results from other studies of workers exposed to aluminium.

A study by White $e t a l^{17}$ included 25 symptomatic pot room workers, who were tested due to suspicion of work related neurological disease. This self selected group performed below the normative levels on several tests of memory and motor functions. An exposure index was correlated to "signs and symptoms of incoordination". As these workers were self selected, and tested because of suspicion of work related disease, it is not relevant to compare these results with those from cross sectional studies of exposed groups of workers.

Sim et $a l$ and Dick et $a l^{19}{ }^{24}$ published reports on a group of workers from the same industry as the study by White et al. ${ }^{17}$ This time the selection of subjects was made by the research team, and a group of 63 potroom workers exposed for more than 10 years was compared with a reference group of 37 non-exposed workers. An increase of the prevalence of three different symptoms (coordination problems, difficulty buttoning, and depression) was reported, but no effects were found in tests of tremor, postural stability, reaction time, or vocabulary.

\section{WELDERS}

In a study of prevalences of symptom for groups of welders with different exposures, Sjögren et $a l^{12}$ analysed responses from 282 workers, among them 65 welding aluminium. All welders responded to the Q16 symptom questionnaire $^{25}$ and two symptoms were specifically related to exposure to aluminium ("do you often have problems with concentrating?" and "do you often feel depressed without reason?"). Furthermore, being employed as an aluminium welder for more than 13 years doubled the risk for reporting more than three symptoms.

In recent years results from two studies of aluminium welders have been published by researchers in Finland. ${ }^{13} 1526$ The first of these studies did not use a control group, but compared data for subgroups of welders with differing exposures. This study ${ }^{13}$ of 17 welders reported dose-effect relations between biological indicators of exposure and performance on four different tests of memory function. The mean concentration of aluminium in urine was $75 \mu \mathrm{g} / \mathrm{l}$. The second paper ${ }^{15}$ reported data from 51 aluminium welders and 28 controls, which were divided into three groups according to the concentrations of aluminium in urine. The low exposure group $(n=28)$ had a mean of $12 \mu \mathrm{g} / 1$, the medium exposed group ( $\mathrm{n}=27)$ had $60 \mu \mathrm{g} / \mathrm{l}$, and the high exposure group $(n=24)$ had 269 $\mu \mathrm{g} / \mathrm{l}$. Dose related effects attributed to aluminium were found on the tests digit symbol, synonyms, embedded figures, memory for designs, and block design. The third paper from this research group reported on the same worker groups, with the addition of some further welders. ${ }^{26}$ An aggregated measure of aluminium body burden was constructed with both urinary and serum concentrations of aluminium. Welders were allotted to one of three groups of workers according to this combined measure of aluminium body burden, and the three groups thus constructed comprised 25, 29 , and 30 workers. The median concentrations of urinary aluminium were 11,49 , and $192 \mu \mathrm{g} / 1 \mathrm{respectively.} \mathrm{There} \mathrm{were} \mathrm{slight} \mathrm{age} \mathrm{dif-}$ ferences between these groups, as the median ages were $37.4,35.7$, and 43.9 respectively. Measurements of symptoms, psychological test performance, and EEG as well as evoked potentials were made. Significant group differences were found for symptoms of fatigue, memory and concentration, and emotional lability. Six of 18 psychological tests also showed significant group differences (Bourdon-Wiersma, counting backwards, dual task cancellation speed, dual task counting speed, synonyms, and memory for designs). Furthermore, there were differences between the exposure groups in the results of the EEG measurements. To evaluate dose-response relations the prevalence of findings in six critical 
domains (symptoms, visual accuracy, attention, verbal, visuospatial memory, and EEG) was examined. The proportion of deviant findings in these domains was between $15 \%$ and $20 \%$. The number of deviant findings was plotted against the combined measure of aluminium body burden, and these data were evaluated. From this evaluation a critical concentration of aluminium was estimated. This concentration corresponded to $110-160$ $\mu \mathrm{g} / 1$ in urine in combination with a serum concentration of $6.7-9.4 \mu \mathrm{g} / 1$.

We studied a group of 38 aluminium welders, ${ }^{14}$ which was compared with a control group of 39 steel welders. The median employment time as an aluminium welder was 15.0 years, and medians for concentrations of aluminium in blood and urine were 3.0 and $22.0 \mu \mathrm{g} / \mathrm{l}$. The reference group had a seniority of 12.0 years. Aluminium welders performed less well than the reference group on four tests of motor functions, and a pegboard test. For the finger tapping and the two tasks of the Luria-Nebraska battery tests this effect was dose-related, and was found in the group of highly exposed welders with a median urinary concentration of aluminium of $59 \mu \mathrm{g} / \mathrm{l}$. In five out of the 19 welders in this highly exposed subgroup the urinary concentration of aluminium exceeded $100 \mu \mathrm{g} / \mathrm{l}$. We did not find any effects on the EEG in these welders.

Bast-Pettersen et $a l^{16}$ studied a group of 20 aluminium welders which was compared with a reference group of construction workers. The welders performed better than the construction workers in several of the tests used. However, when performance of the welders was analysed separately, significant correlations were found between the duration of exposure in years and poorer performance on the tremor test. Performance on a test of reaction time was found to be worse for workers with increasing concentrations of aluminium in the air. The median aluminium concentration in urine for this group was $41 \mu \mathrm{g} / \mathrm{l}$, and the range was $19-129 \mu \mathrm{g} / 1$.

ALUMINIUM POWDER EXPOSURE

In a German study 32 workers exposed to powder were compared with 30 referents. ${ }^{20}$ The median exposure time was 13 years and the median urinary concentration of aluminium was $110 \mu \mathrm{g} / \mathrm{l}$. No differences were found between the groups in the tests performed.

Between 1944 and 1979 McIntyre powder, consisting of finely ground aluminium and aluminium oxides, was used as a prophylactic agent against silicotic disease in mines in Ontario, Canada. The miners inhaled the aluminium particles for 10 minutes before each underground shift. Performance of a group of 261 miners exposed to aluminium was compared with that of 346 unexposed miners in three cognitive tests. Four per cent of the unexposed miners had impaired cognitive functions, $10 \%$ of the miners with $0.5-9.9$ years of exposure, $15 \%$ of the miners with $10.0-19.9$ years of exposure, and $20 \%$ of miners with more than 20 years of exposure. ${ }^{11}$ Thus, this study showed a clear dose-response relation.

In the present study, the workers exposed to flake powder had a significantly lower score on the tracking test compared with the mild steel welders, but performed better compared with the smelters in many tests despite higher concentrations of aluminium in urine. The workers producing aluminium flake powder had clearly the highest concentrations of aluminium in urine of our study groups. The normal concentration of aluminium in urine is below $10 \mu \mathrm{g} / 1 .{ }^{1}$ In a previous study of the same industry the median concentrations of aluminium in urine of the flake powder producers was $220 \mu \mathrm{g} / \mathrm{l}$ (range 32-345), ${ }^{9}$ and in the present study it was $83 \mu \mathrm{g} / 1$ (range 12-282). Obviously the exposure to aluminium has been reduced for these workers as a group. This reduction is partly due to reduced exposure at the work site, and partly it is due to recent personnel turnover, resulting in a relatively young work force.

These two studies of workers exposed to aluminium during powder production both report urinary concentrations even higher than those found in some of the welder groups. Therefore, it is notable that no apparent effects from this exposure have been reported with powder producers.

A clear dose-response relation was found among the Canadian miners exposed to aluminium. However, neither blood nor urine concentrations of aluminium were measured. These miners were exposed for a longer time than the two groups of powder production workers. These two groups of workers have urinary concentrations even higher than those found in some of the welder groups. Therefore, it is notable that no apparent effects from this exposure have been reported among workers in powder production.

\section{URINARY ALUMINIUM CONCENTRATIONS}

The concentrations of aluminium in urine after the shift in the welders were calculated according to an equation determined in a previous study. ${ }^{8}$ The reason for this calculation was to have sample data from a time in common for all the welders. This calculation could be performed because excretion of urinary aluminium among welders has been comparatively well studied. ${ }^{1}$

All smelter workers were investigated 16 hours or more after their latest exposure. A previous study of seven pot room workers showed a half life of 7.5 hours for urinary concentrations of aluminium. ${ }^{27}$ However, if this information had been used to calculate concentrations after the shift in our study, the resulting values after the shift would most probably have been overestimations of the true values. The pot room workers in our group were studied in 1980, and the highest concentration of aluminium after the shift found was $20 \mu \mathrm{g} / 1$.

Most of the flake powder production workers were studied after 5 days free from exposure. An earlier investigation of such workers, who were followed up for $4-5$ weeks 
without exposure, showed a half life for concentrations of aluminium in urine of 5-6 weeks. ${ }^{9}$ A calculated concentration after the shift could be about $10 \%$ higher than the measured one, however, this estimation is based on much weaker background information compared with the welders.

\section{Conclusion}

The concentrations of aluminium in blood and urine are affected by short term and long term occupational exposure. Samples collected immediately after a work shift are strongly related to the current exposure, whereas samples taken later in the period after exposure reflect cumulative exposure, that is, the body burden of aluminium. This dose estimate is probably better for assessing many health risks. However, it is not known how well concentrations of aluminium in blood and urine reflect the concentrations in the target tissues, such as the brain, among workers exposed to different species of aluminium.

Neurotoxic effects have been found in welders with urinary concentrations of aluminium above $100 \mu \mathrm{g} / \mathrm{l}$ compared with welders with lower levels. The consistency in these findings is probably explained by the fact that the welders are compared with other welders, being similar in most respects except the exposure to aluminium. It should be emphasised that knowledge is lacking whether these effects are reversible or not. The only country with a limit value for aluminium in urine after the shift is Germany, and the adopted limit value is 200 $\mu \mathrm{g} / 1 .{ }^{28}$ According to recently published findings this concentration seems to be too high to sufficiently protect aluminium welders.

Neurotoxic effects have not been found in workers exposed to powder despite high urinary concentrations of aluminium. This fact needs to be further studied.

The Swedish Council for Work Life Research supported the studies of welders and of pot room and foundry workers financially. All three studies were financially supported in part by the companies studied. The study design was approved by the regional ethics committee at the Karolinska Institute in Stockholm.

1 Sjögren B, Elinder C-G, Iregren A, et al. Occupational aluminum exposure and its health effects. In: Yokel R, Golub $\mathrm{M}$, eds. Research issues in aluminum toxicity. Washington, DC: Taylor and Francis, 1997:165-83.

2 Alfrey A, LeGendre G, Kaehny W. The dialysis encephalopathy syndrome. $N$ Engl f Med 1976;294:184-8.

3 Alfrey A, Froment D. Dialysis encephalopathy. In: De Broe M, Coburn J, eds. Aluminium and renal failure. Dordrecht: Kluwer Academic Publishers, 1990:249-57.
4 Yokel R, Provan S, Meyer J, et al. Aluminum intoxication and the victim of Alzheimer's disease: similarities and differences. Neurotoxicology 1988;9:429-42.

5 Savory J, Exley C, Forbes W, et al. Can the controversy of the role of aluminium in Alzheimer's disease be resolved? $f$ Toxicol Environ Health 1996;48:615-35.

6 McLachlan D. Aluminium and the risk for Alzheimer's disease. Environmetrics 1995;6:233-75.

7 Sjögren B, Lundberg I, Lidums V. Aluminium in the blood and urine of industrially exposed workers. $\mathrm{Br} F$ Ind $\mathrm{Med}$ 1983;40:301-4

8 Sjögren B, Elinder C, Lidums V, et al. Uptake and urinary excretion of aluminium during welding. Int Arch Occup Environ Health 1988;60:77-9.

9 Ljunggren K, Lidums V, Sjögren B. Blood and urine levels of aluminium among workers exposed to aluminium flakes. Br f Ind Med 1991;48:106-9.

10 Hosovski E, Mastelica Z, Sunderic D, et al. Mental abilities of workers exposed to aluminum. Med Lav 1990;81:1193

11 Rifat S, Eastwood M, Crapper McLachlan D, et al. Effects of exposure of miners to aluminum powder. Lancet 1990;336:1162-5.

12 Sjögren B, Gustavsson P, Hogstedt C. Neuropsychiatric symptoms among welders exposed to neurotoxic metals. $\mathrm{Br}$ F Ind Med 1990;47:704-7.

13 Hänninen $\mathrm{H}$, Matikainen E, Kovala $\mathrm{T}$, et al. Internal load of aluminium and the central nervous system function of aluminium workers. Scand f Work Environ Health 1994;20: 279-85.

14 Sjögren B, Iregren A, Frech W, et al. Effects on the nervous system among welders exposed to aluminium and manganese. Occup Environ Med 1996;53:32-40.

15 Akila R, Stollery B, Riihimäki V. Decrements in cognitive performance in metal inert gas welders exposed to aluminium. Occup Environ Med 1999;56:632-9.

16 Bast-Pettersen R, Skaug V, Ellingsen D, et al. Neurobehavoral performance in aluminium welders. Am f Ind Med 2000;37:184-92.

17 White D, Longstreth W, Rosenstock L, et al. Neurologic syndrome in 25 workers from an aluminum smelting plant. Arch Intern Med 1992;152:1443-8.

18 Bast-Pettersen R, Drablös P, Goffeng L, et al. Neuropsychological deficit among elderly workers in aluminum production. Am f Ind Med 1994;25:649-62.

19 Sim M, Dick R, Russo J, et al. Are aluminium potroom workers at increased risk of neurological disorders? Occup Environ Med 1997;54:229-35.

20 Lang C, Letzel S. Neurotoxicität von Aluminium. Fortschritte der Medizin 1995;113:30-1.

21 Iregren A, Gamberale F, Kjellberg A. SPES: a psychological test system to diagnose environmental hazards. Neurotoxicol Teratol 1996;18:485-91.

22 Golden C. Diagnosis and rehabilitation in clinical psychology. Springfield, Illinois: Charles C Thomas, 1981.

23 Baldwin M, Mergler D, Larribe F, et al. Bioindicator and exposure data for a population based study of manganese. Neurotoxicology 1999;20:343-54.

24 Dick R, Krieg Jr E, Sim M, et al. Evaluation of tremor in aluminium production workers. Neurotoxicol Teratol 1997; 19:447-53.

25 Hogstedt C, Andersson K, Hane M. A questionnaire approach to the monitoring of early disturbances in central nervous functions. In: Aitio A, Riihimäki V, Vainio E, eds. The biological monitoring and surveillance of workers exposed to chemicals. Washington: Hemisphere, 1984:275-87.

26 Riihimäki V, Hänninen H, Akila R, et al. Body burden of aluminum in relation to central nervous system function among metal inert-gas welders. Scand 7 Work Environ Health 2000;26:118-30.

27 Pierre F, Baruthio F, Diebold F, et al. Effects of different exposure compounds on urinary kinetics of aluminium and fouride in industrially exposed workers. Occup Environ Med 1995;52:396-403.

28 Deutsche Forschungsgemeinschaft. Biological exposure values for occupational toxicants and carcinogens. Weinheim, Germany: VCH Verlagsgesellschaft, 1994.

\section{Rejected manuscripts}

Authors whose submitted articles are rejected will be advised of the decision and one copy of the article, together with any reviewer's comments, will be returned to them. The
Fournal will destroy remaining copies of the article but correspondence and reviewers' comments will be kept. 